\title{
Payment Mechanisms for Winter Road Maintenance Services
}

Adel Abdi, Hans Lind and Björn Birgisson, (KTH Royal Institute of Technology, Sweden)

\begin{abstract}
In countries with severe winters, a major portion of the annual budget for road maintenance is allocated to winter road maintenance. Thus it is important to identify an appropriate basis for the remuneration of the entrepreneurs who carry out the maintenance tasks, one that minimises or eliminates disputes and that satisfies both client organisations and contractors. The objective of this study is to investigate and evaluate the payment models applied in Sweden for winter road maintenance services and suggest possible improvements. Inadequate reimbursement models lead either to unnecessary cost overruns that affect the client's annual budget or cause cash flow problems for the contractor, which can result in safety issues. To solve the problems associated with paying for just-in-time road maintenance, cold region countries such as Sweden have developed various remuneration models, including some based on what is known as the Weather Index. The study uses a domestic questionnaire survey, analysis of a number of current contract documents, a series of meetings with project managers followed by an international benchmarking investigation. The study identified four winter maintenance remuneration models of which one is based on weather data. The study reveals that the payment model based on weather data statistics is applied only to roads with higher traffic flow and generates the most uncertainty about costs. Possible improvements should include more reliable weather data obtained from weather stations and bonuses related to customer satisfaction.
\end{abstract}

Keywords: Road maintenance, Winter maintenance services, Contract, Payment mechanism, Remuneration models

\section{Introduction}

Retaining the value of a country's existing infrastructure is extremely important for a healthy national economy. However, maintenance of infrastructure such as a road network is both difficult and costly because it is spread over a large geographical area and the tasks required are diverse and fragmented ( $\mathrm{Ng} \&$ Wong, 2007). It is even more difficult and expensive when the tasks are performed during winter. Yet any reduction in the budget for performing these tasks increases the vulnerability of the infrastructure (Jaarsma \& van Dijk, 2002).

When outsourcing and contracting road infrastructure maintenance services, the main concept behind the payment mechanism is that contractors are compensated for services performed (Aziz, 2007). However, identifying the optimum payment method presents a challenge for road and transport authorities, which are subject to budget constraints. A fair remuneration model is a requirement if cost effective, quality services are to be performed in a timely manner. Such a model also acts as an incentive for contractors to tender for road maintenance projects. As Motawa \& Kaka (2009) show, clear identification of an appropriate payment mechanism contributes to fair payment to contractors and improved work performance.

Most contractors engage subcontractors with the necessary skills for some of the contracted tasks to make up for the skills they lack. Subcontractors, in particular small and mediumsized contracting companies, consider an appropriate form of remuneration a vital factor in 
performing the tasks on schedule and to the required quality. In this connection, Judi \& Rashid (2010) found that the financial capacity of most contractors is limited and that keeping their cash-flow in balance depends directly on how they get paid for work done, thus enabling them to continue operating.

Even medium-sized contractors in the supply chain need to hire service providers and suppliers to perform their contracted tasks. Improper payment methods can result in delays in performing the work and reduction of profitability, which also leads to traffic disruption and delay. Motawa \& Kaka (2009) even show that many contractors try to minimise the outstanding balances owed by clients and increase project cash flow either by increasing efficiency (e.g. by instituting more effective management processes) or by resorting to unfair tactics such as over-measurement and delay in payment of subcontractors.

Although winter highway maintenance services seem limited and controllable tasks, the fact that these activities have serious consequences for society and are easily affected by unpredictable factors (such as improper payment models) had led to their being recognized as important, extensive and complex.

Winter maintenance of the state road network in Sweden is performed by the Swedish Transport Administration (STA) and integrated into a comprehensive road maintenance contract. A hybrid payment mechanism is applied in the contract, partly for performance of year-round services and partly for winter services. When contracting road maintenance services, STA is interested in just-in-time service delivery before the contractor is paid. The payment model for winter maintenance is based particularly on weather characteristics that are addressed in the contract documents.

The objective of this study is to describe and analyse different dimensions of the payment system for winter road maintenance, both from a theoretical perspective and in relation to practical feasibility. The focus is on the current Swedish system and how it can be improved.

\section{Theoretical Background}

When developing the basic structure of a payment system, four principles should be addressed. The first basic principle is the measurability of the contracted and the performed services (i.e. the performed services should be measurable both qualitatively and quantitatively). A third party (e.g. a court) must be able to evaluate whether the work has been carried out as agreed. For example, according to the Irish Department of the Environment and Local Government Note 12 (2000) performance-based payment should be based upon achieving standards that are practically measurable during the whole period of the contract. Mattsson \& Lind (2009) indicate that problems can arise in contracts where payments are subject to the results achieved or subject to keeping a road in a certain condition. There is often disagreement about whether the specific standards were met. This can be an especially large problem in winter maintenance contracts as road conditions can change very quickly.

The second basic principle, also underlined by the Irish authority (2000) is that the payment system has to be simple enough to be understandable. The third basic principle is the inclusion of proper incentives within a specific payment mechanism. Should there be a fixed payment for the services to be performed, or should there be a payment for a specific action carried out? As will be discussed below, a fixed payment can lead to contractors doing too little, while paying according to work actually carried out can lead to contractors doing too much. In this context, Motawa \& Kaka $(2008,2009)$ state that both payment mechanisms have advantages and disadvantages.

The fourth basic principle in designing a payment mechanism is the allocation of risk. Winter conditions vary from year to year. In some years a lot of work is needed to guarantee certain

Abdi, A et al (2013) 'Payment mechanisms for winter road maintenance services', Australasian Journal of Construction Economics and Building, 13 (4) 18-31 
results for each type of road, while in other years much less work is needed. A fixed payment puts this risk on the contractor, while payment in relation to the work carried out puts the risk on the client. As discussed in Mattsson \& Lind (2009), putting greater risk on the contractor can lead to reduced competition as smaller and risk-averse companies may not be willing to bid for such a contract.

As Aziz (2007) states, in order to develop payment systems, existing payment systems should be studied and analysed so that the information can be used to create new payment mechanisms. Råsled (1992) claims that the difficulty level of a project, product or service has a crucial and decisive influence on whether a certain payment model (e.g. unit-price) is advisable and feasible, or whether payment should be based on cost accounting.

\section{Payment Framework in Sweden}

\section{The Legal Framework}

While all public procurement and contracting within the construction industry in Sweden is governed by European Union (EU) directive 2004/18/EC incorporated into the Swedish Act on Public Procurement (see Abdi, Lind \& Birgisson, 2013b), the payment mechanism for the total contract is governed by the domestic agreement General Condition of Contract for Design and Construct Contracts for Building, Civil Engineering and Installation Works - ABT 06. The agreement is a legal document that all the actors in the Swedish construction industry regard as the basis for how payment should be implemented. Road maintenance services in Sweden are performed according to a so-called total contract, described as a turnkey contract for the execution of the operation and maintenance of public roads. This means the payment system for this type of contract is also regulated by this legal document. International contractors who are awarded a contract to perform projects in Sweden have to follow this agreement. An important question is how flexible or rigid this document is, but that is beyond the scope of this study.

\section{Contract Type}

In Sweden, road maintenance is divided into routine and structural maintenance. Routine or corrective maintenance is the work required to maintain the functionality of the road network all year long to specific road standards. Structural or preventive maintenance is the work required to maintain the whole road asset for long term usage by maintaining and improving the asset's values. In order to facilitate road maintenance services, the whole Swedish road network is divided into 115 maintenance areas $\left(1^{\text {st }}\right.$ September 2012) within STA's six regional administrative directorates. A routine maintenance contract is procured area-wide (i.e. one contract per maintenance area). Winter road maintenance services are bundled with other road maintenance services into Area Maintenance Contracts (AMC). Abdi, Lind \& Birgisson (2013b) discuss whether this kind of bundled contract is the best option.

\section{Empirical Investigations - Method and Results}

Earlier studies (Abdi, 2011; Abdi, Lind \& Birgisson, 2013c) revealed diffuse and widespread dissatisfaction with the procurement procedure and contracts for current Swedish winter maintenance services. The outcome of these studies motivated additional study to gain insight into the payment system and how it is linked to the whole maintenance performance procedure.

This research started with a domestic questionnaire survey and continued by collecting a number of current AMC documents, with the support of Swedish Transport Administration (STA), for analysis and evaluation. The questionnaire for the domestic survey was designed with a total of 70 questions divided into four themes. Totally 41 questionnaires were sent to a number of selected experienced staff at 18 Swedish client organisations and contracting companies. The core theme for this part of the study was the payment system used in road maintenance contracts including winter road maintenance. A series of meetings with a

Abdi, A et al (2013) 'Payment mechanisms for winter road maintenance services', Australasian Journal of Construction Economics and Building, 13 (4) 18-31 
number of project managers was also conducted to collect their insight into the current payment system. An international benchmarking investigation was also carried out by requesting information from a number of Road and Transport Authorities (RTA) around the world with climates similar to Sweden. The selected RTA were from Washington DC, USA; Ontario, Canada; Finland; Norway; Iceland; Denmark; Estonia; Lithuania; Latvia; England; Austria and Japan. Six of the twelve selected RTA responded to the request. The results of each avenue of research are described in the corresponding subsections below.

\section{Selected Results of the Domestic Survey}

The responses to the questionnaire revealed that there are two basic forms of remuneration for all road maintenance tasks performed year round, which thus include winter maintenance: performance-based and prescribed payments. Both forms are based on a fixed pricing model for one to two years, depending on the maintenance area and the contract length. After the end of the initial year (or two years) indexing is applied to the remaining contract period. Every month the contractor is entitled to payments partly on a performance basis and partly according to a prescribed payment plan. The performance basis is intended to adjust for quantities (fixed unit-price multiplied by actual agreed quantities). The prescribed payment plan is set up annually by the clients. This latter form of compensation is intended for non-adjustable quantities (fixed costs) according to the bill of quantities. Usually, the prescribed fixed payment is intended for the contractor's winter organisation and cannot be counted as an adjustable amount. The results from examining current AMC documents confirmed this after reviewing and analysing five randomly chosen maintenance areas across Sweden. The analysis of the contract documents also revealed that there are advance payment rules in some AMC, but not in others. Figure 1 gives an overview of the payment mechanism for road maintenance services in Sweden where AMC stands for Area Maintenance Contract.

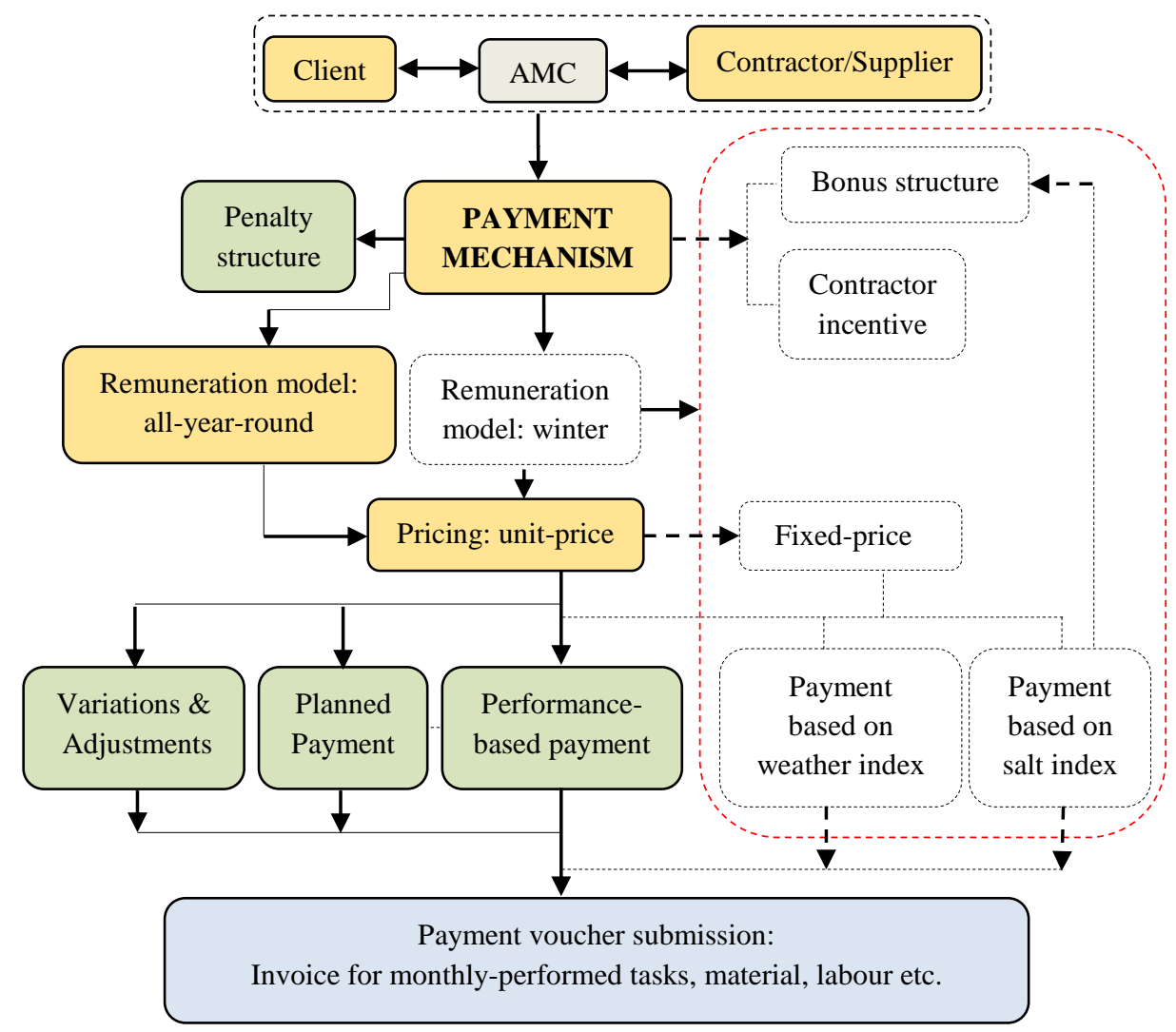

Figure 1 Flow chart of the Swedish payment mechanism for road AMC

Abdi, A et al (2013) 'Payment mechanisms for winter road maintenance services', Australasian Journal of Construction Economics and Building, 13 (4) 18-31 


\section{Payment System for Winter Road Maintenance}

Although winter road maintenance services are integrated into the AMC (as mentioned earlier), additional rules apply in the payment system for performance of these services. These rules vary from maintenance area to maintenance area due to different regional and area-specific circumstances. Some contracts that were awarded some years ago are still valid and are driven by older rules, while other contracts are newer with revised rules. Currently, there are a number of different remuneration models for winter maintenance adapted to different maintenance contracts. Winter models generally consist of fixed and variable components that are similar to the remuneration of the other road maintenance models. However, the mechanism for payment of winter road maintenance differs based on weather data and outcomes, making them rather complicated and in some cases unclear and uncertain.

\begin{tabular}{|c|c|c|}
\hline \multicolumn{2}{|c|}{ Weather situation } & Weather outcome and condition \\
\hline \multicolumn{2}{|c|}{ Group H1 } & Number of weather outcomes of type HR1, HR2 and HS \\
\hline HR1 & $\begin{array}{l}\text { Slippery road surface } \\
\text { due to moderate hoar } \\
\text { frost }\end{array}$ & $\begin{array}{l}\text { Road surface temperature is at least } 0.5^{\circ} \mathrm{C} \text { lower than dew point } \\
\text { temperature or road surface temperature is lower than }+1.0^{\circ} \mathrm{C}\end{array}$ \\
\hline HR2 & $\begin{array}{l}\text { Slippery road surface } \\
\text { due to heavy hoar } \\
\text { frost }\end{array}$ & $\begin{array}{l}\text { Road surface temperature is at least } 2.0^{\circ} \mathrm{C} \text { lower than dew point } \\
\text { temperature or road surface temperature is lower than }+1.0^{\circ} \mathrm{C}\end{array}$ \\
\hline HS & $\begin{array}{l}\text { Slippery road surface } \\
\text { due to light snowfall }\end{array}$ & $\begin{array}{l}\text { Amount of accumulated snow is between } 0.01 \text { and } 0.50 \mathrm{~cm} \text { at a } \\
\text { temperature between }+1.0^{\circ} \mathrm{C} \text { and }-10.0^{\circ} \mathrm{C} \text { during a snow period of } \\
\text { highest } 4 \mathrm{~h}\end{array}$ \\
\hline \multicolumn{2}{|c|}{ Group H2 } & Number of weather outcomes of type HT and HN \\
\hline HT & $\begin{array}{l}\text { Slippery road surface } \\
\text { due to moist /wet } \\
\text { surface freezing }\end{array}$ & $\begin{array}{l}\text { Wet road surface temperature drops below }+1.0^{\circ} \mathrm{C} \text { due rain, snow or } \\
\text { sleet under } 12 \text { hours }\end{array}$ \\
\hline $\mathrm{HN}$ & $\begin{array}{l}\text { Slippery road surface } \\
\text { due to rain or sleet on } \\
\text { cold surface }\end{array}$ & Road surface temperature is lower than $+1.0^{\circ} \mathrm{C}$ due to rainfall or sleet \\
\hline \multicolumn{2}{|c|}{ Group S1 } & $\begin{array}{l}\text { Number of weather outcomes of type } S \text { and } D \text { both with snow } \\
\text { amount }>0.51 \mathrm{~cm} \text { per interval of highest } 4 \text { hours. }\end{array}$ \\
\hline S & Snowfall & Precipitation is snow \\
\hline $\mathrm{D}$ & Drifting snow & $\begin{array}{l}\text { Wind speed at least } 6 \mathrm{~m} / \mathrm{s} \text { under at least } 4 \mathrm{~h} \text { in average and if drift- } \\
\text { capable snow is presented }\end{array}$ \\
\hline \multicolumn{2}{|c|}{ Group S2 } & $\begin{array}{l}\text { Number of weather outcomes of type D with amount of snow } \\
\leq 0.50 \mathrm{~cm} \text { per interval of highest } 4 \text { hours }\end{array}$ \\
\hline $\mathrm{D}$ & Drifting snow & $\begin{array}{l}\text { Wind speed at least } 6 \mathrm{~m} / \mathrm{s} \text { under at least } 4 \mathrm{~h} \text { in average and if drift- } \\
\text { capable snow is presented }\end{array}$ \\
\hline
\end{tabular}

Table 1 Weather situations generated by WI from basic data of RWIS and the output groups (Source: STA, 2012)

Information about weather is obtained from a Weather Index $(\mathrm{WI})^{2}$ developed by the STA. The WI is the basis on which contractors to plan and perform their tasks, and then receive payments for the work done during winter. This index is also a compensation model through which the payment for winter road maintenance services is calculated. The WI for each area is calculated partly by a number of climate factors. Basic raw data is obtained from weather stations within a maintenance area connected to the STA's Road Weather Information System (RWIS), and partly from scaled Mesoscale Analysis System (MESAN scaled) weather data obtained from the Swedish Meteorological and Hydrological Institute (SMHI). The raw data from RWIS consists of air temperature, road surface temperature, dew point temperature, relative humidity, type and amount of precipitation, and wind speed. MESAN

\footnotetext{
${ }^{1}$ A deposit of interlocking ice crystals formed by direct sublimation on a surface, sometimes referred to as Rime Frost (EU Cost 344, 2002)

${ }^{2} \mathrm{WI}$ is a further development of an earlier software program used for winter remuneration model 'Weather Compensation Combination'(Swedish: VädErsKombi)
}

Abdi, A et al (2013) 'Payment mechanisms for winter road maintenance services', Australasian Journal of Construction Economics and Building, 13 (4) 18-31 
analysis is a compilation of all conceivable meteorological observations around the clock. The data obtained from MESAN are average values over a $22 \times 22 \mathrm{~km}$ wide area, while the RWIS data are area-specific values. Each kind of obtained data is weighted depending on its quality. Different weather situations are generated as items by $\mathrm{WI}$ and are divided into four different groups of weather outcomes that are presented in the output of the WI software program (Table 1).

In addition to the above weather situations, two other weather situations have to be accessed by entrepreneurs, namely special weather SV1 and SV2. Special weather SV1 is a weather situation where the wind speed is at least $10 \mathrm{~m} / \mathrm{sec}$ for 6 hours and there is risk of snowdrifts. Special weather SV2 is a weather situation with snow intensity of at least 1.5 $\mathrm{cm} / \mathrm{h}$ for 15 hours. In both cases, entrepreneurs have to use all available resources for organising their maintenance tasks. The remuneration in such severe situations is on a time and materials basis.

The way outcomes in Table 1 are compensated for depends on the amount of each item. A severe winter may generate eight HR1s and four HR2s monthly, while a mild winter may generate fewer HRs per month. Payment for all work performed is made after the average of the amount of items in the $\mathrm{H}$ and $\mathrm{S}$ groups has been calculated. The unit-price for each item in each group has already been priced in the bill of quantities.

The Swedish road network is divided into five classes (Table 2) according to traffic flow (Annual Average Daily Traffic - AADT), and the compensation of contractors for the winter tasks varies between classes.

\begin{tabular}{|c|c|c|c|c|c|}
\hline $\begin{array}{c}\text { Traffic flow } \\
(\text { AADT })\end{array}$ & $>16000$ & $\mathbf{8 0 0 0 - 1 6 0 0 0}$ & $\mathbf{2 0 0 0 - 7 9 9 9}$ & $\mathbf{5 0 0 - 1 9 9 9}$ & $<500$ \\
\hline Road class & 1 & 2 & 3 & 4 & 5 \\
\hline
\end{tabular}

Table 2 Road classification in Sweden (Source: STA 2012)

There are two models for the variable remuneration part of the payment mechanism for winter measures. The first model is based on weather outcomes from WI and applies only to road classes 1 to 3 . The second one is intended for the implemented measures per $\mathrm{km}$ road and applies only to road classes 4 to 5 . The variable compensation for road classes 1 to 3 is priced in the bill of quantities per weather outcomes. The amount is adjustable for the actual number of weather outcomes according to the WI. The amount in the bill of quantities is calculated based on the statistics of the past five years. The variable compensation for road classes 4 to 5 is priced in the bill of quantities per road class and road kilometre $(\mathrm{km})$ performed services, excluding de-icing materials. De-icing materials for road class 4 to 5 are reimbursed separately according to actual quantity used and according to the client's specified unit-price in the bill of quantities.

The fixed remuneration covers the fixed costs of the contractor's winter organisation that are weather-dependent. The payment system based on weather data statistics is common to all 115 existing AMC for performed winter road services. In addition to the weather index, a salt index is applied in the contracts. This describes the actual salt consumption compared to the client-recommended use of salt for each type of weather situation. While the structure includes a penalty in the payment mechanism for performance of both winter and other road maintenance services, the bonus structure is intended to create incentives for contractors to reduce salt consumption during winter. Thus the payment mechanism is influenced by a bonus system which only aims to reduce salt consumption during winter, nothing else. 


\section{Meeting with the Project Managers}

A series of meetings were conducted with a number of the client organisation's project managers to confirm the obtained data by analysing contract documents and to understand other possible concerns with the current payment systems. Almost all the managers who work with the client organisation agreed that the payment mechanism is far from perfect, particularly during severe winters. They also stated that the current remuneration model based on WI is very complicated and there are a number of uncertainties in the model. Moreover a lack of skilled personnel using the WI also affects payments. In some cases, the complexity of the current model has led to disputes. A number of managers stated that the model works in certain areas, but not in others.

Some project managers said that before a contractor is compensated for work done, the performed tasks have to be followed up and verified by a Global Positioning System (GPS). This verification method is intended for road classes 4 to 5 . This method does not function within all maintenance areas. Follow-up and verification of performed measures for km-road by GPS is not always easy to sort out.

The survey recognised at least four remuneration models in the payment mechanism for winter road maintenance services, summarised as follows:

- Remuneration with variable costs, where payment depends on how long the measures have taken, that is, the contractor is reimbursed by SEK/h (Swedish kronor per hour)

- Remuneration with variable costs with time (h) incentives, where the contractor gets paid per hour for work done during winter season. After the end of the winter season, payments are reconciled with the contractor according to the weather outcomes (WI) model

- Remuneration with variable costs with road length (SEK/ km) incentives, where the contractor gets paid per km-road and reconciliation is made with the contractor after the season

- Remuneration according to the weather outcomes (WI) where the unit-price is already priced in the bill of quantities for different weather situations (Table 1)

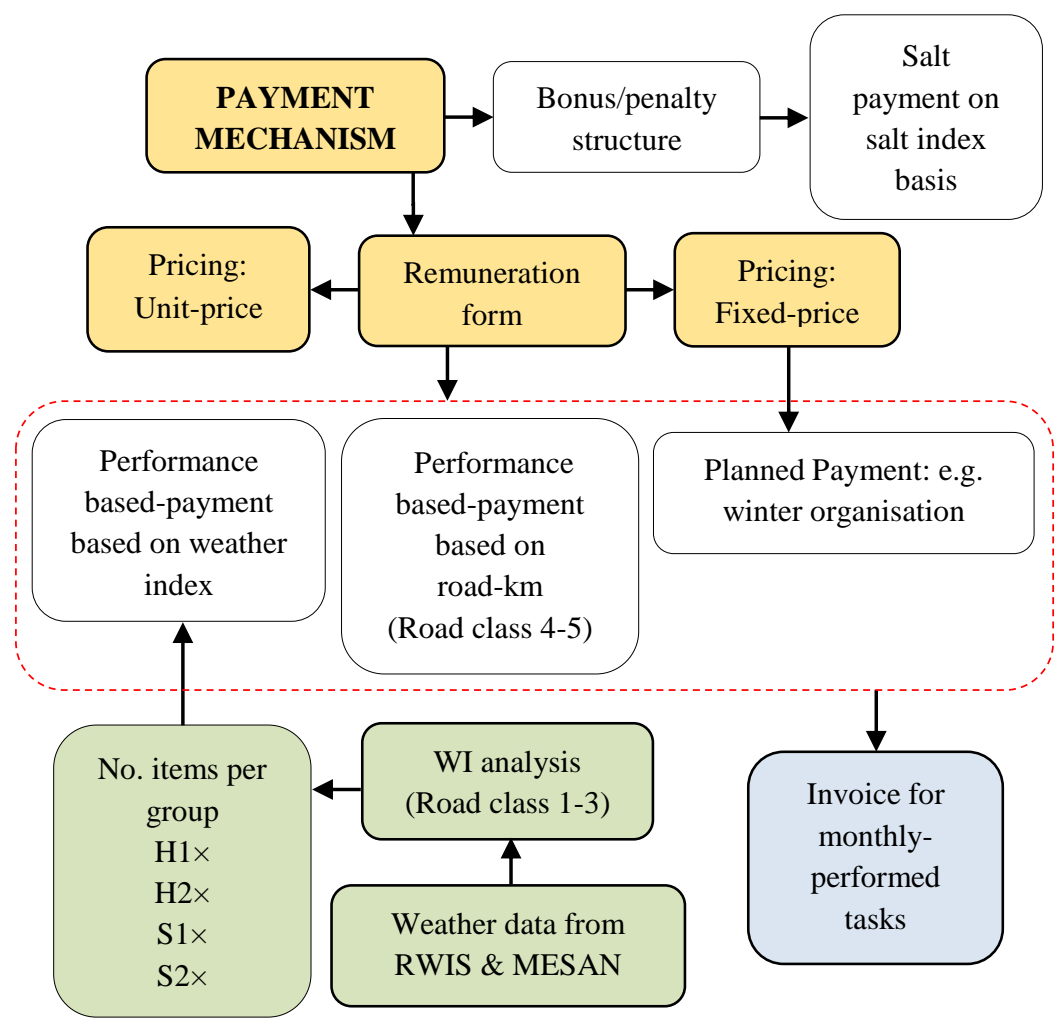

Figure 2 Flow chart of the Swedish payment mechanism for winter road maintenance

Abdi, A et al (2013) 'Payment mechanisms for winter road maintenance services', Australasian Journal of Construction Economics and Building, 13 (4) 18-31 
Because contracts are different in different areas with different contract durations, the models differ from one area to another. The two last models are newer ones that are applied in newly procured contracts, while the former two have already been applied in some Area Maintenance Contracts (AMC). Figure 2 illustrates how the contractor receives payment for winter road services.

\section{Selected Results from the International Survey}

Concerning payment method for winter road maintenance, the obtained responses from six of twelve responding Road and Transport Authorities (RTA) in Canada; Ontario, Denmark, Finland, Iceland, Lithuania and Estonia show that winter road maintenance is often organised differently from one RTA to another. The level of knowledge and experience in selecting and applying appropriate payment mechanisms also varies between RTA in different countries. According to the responses submitted, winter maintenance services are integrated into one road maintenance contract (i.e. bundled with other road maintenance services) in all the responding RTA except one. Concerning forms of remuneration, there is a clear difference between the six responding RTA. While variable payment related to the amount of work performed is used in Demark and Lithuania, fixed-price payment is used in Estonia and Ontario, Canada. Finland and Iceland apply both the fixed-price and variable model. Figure 3 is a compilation of the benchmarking study and gives an overview of the payment mechanism for road maintenance services in the responding countries' RTA. Note that the boxes enclosed by dashed lines show the components that are not included in the payment mechanism in the specific country listed at the top of the column.

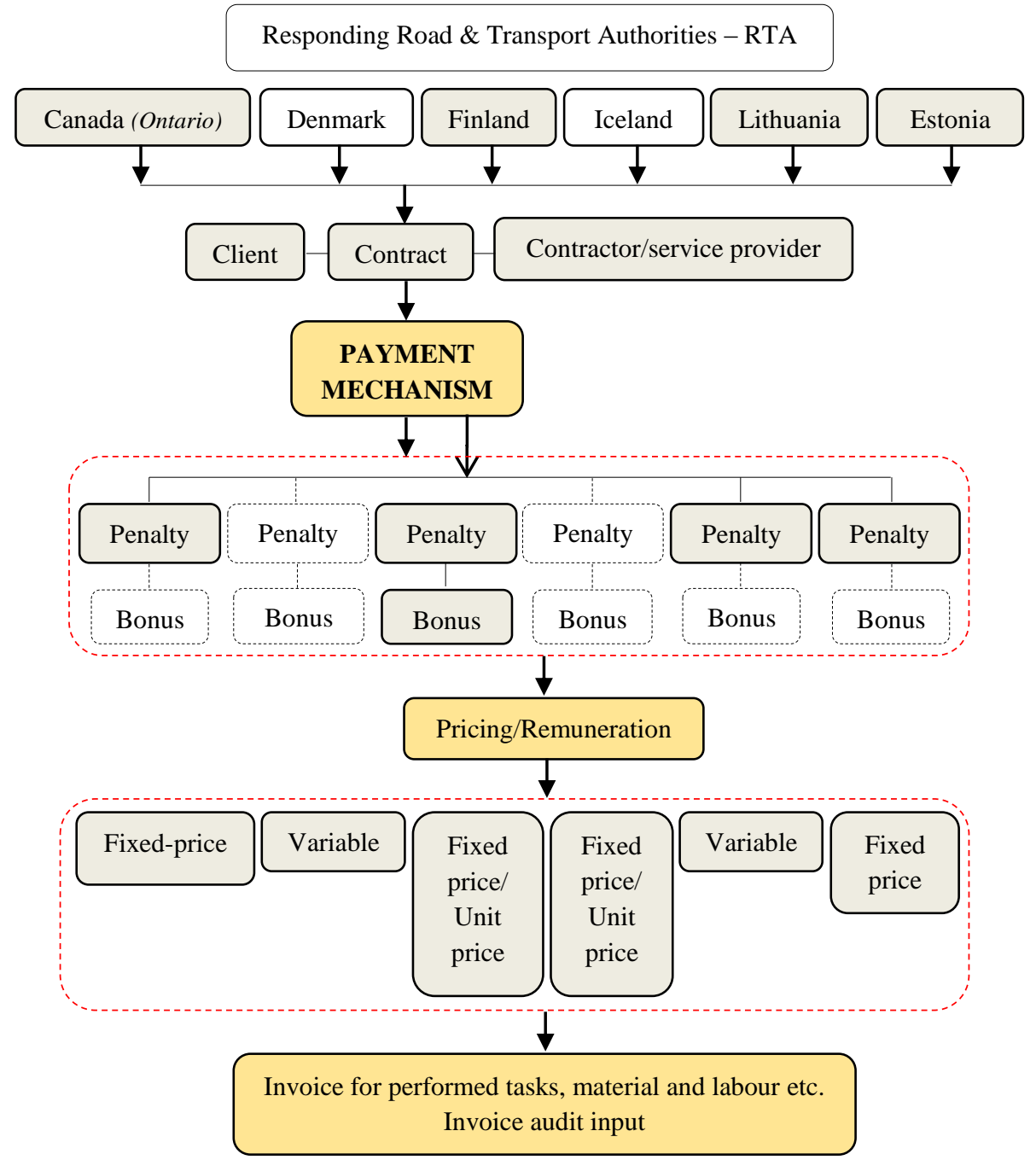

Figure 3 Schematic representation of the payment mechanism in the studied countries

Abdi, A et al (2013) 'Payment mechanisms for winter road maintenance services', Australasian Journal of Construction Economics and Building, 13 (4) 18-31 
As the information from the responding Road and Transport Authorities (RTA) shows, there are similarities to Sweden's area-wide contracts with different durations being applied in some responding countries like Finland and Ontario, Canada.

Concerning the inclusion of penalties and bonuses in the contract, three responding RTA apply only penalties (Ontario, Lithuania and Estonia), two of them apply neither penalties nor bonuses (Denmark and Iceland), and only one RTA applies both penalties and bonuses (Finland). The penalty and bonus components in the payment mechanism cover not only winter maintenance but also other road maintenance services (see Figure 3). The way in which penalties are applied is as follows:

- Penalties are applied if the quality of performed work is poor after inspection. If the work is finished ahead of schedule with the required quality, extra payment will be available (Finland).

- Penalties are applied if the quality does not meet ISO standards. No bonus is available (Ontario, Canada).

- Penalties, as determined in the contract, are applied if the requirements for road conditions are not met. There are no bonuses (Estonia).

- Although the contractors are state-owned contracting companies, they still face penalties if they do not follow the requirements in the contract (Lithuania).

When asked 'If the performed work is paid by variable payment related to the amount of work performed, there is risk that you have to pay for more work than is actually carried out', only one responding RTA, which applies the variable remuneration model, totally agreed with the statement. Three of them partly agreed and one totally disagreed. Three commented as follows:

- In Denmark, the performed work is logged and followed up through the winter management system, otherwise there is risk of paying more for less performed work (agree with question)

- In Iceland, the service vehicles are tracked, thus there is no risk of paying more for less work done (disagree)

- In Lithuania, there is full control over the situation by monthly follow-up of the amount of performed work according to the contract, which is clearly stated in the contract (disagree)

When asked 'If the performed work is paid by fixed-price, there is risk that all the measures are not performed correctly', only one responding RTA, which applies the fixed-price remuneration model, totally disagrees with the statement. Three of them partly agreed and one totally agreed with this statement. Additional comments were received from two RTA:

- Ontario, Canada, disagreed with the statement and commented that the contract states clearly what performance levels are to be met. Penalties are applied if performance levels are not met.

- Denmark agreed with the statement and commented that they follow the performed work through their winter system management just as they followed for the variable payment method.

Note that in Denmark road maintenance services are performed partly in-house and partly outsourced.

Four of the six responding countries use WI to facilitate organisational and payment mechanisms for winter tasks just as Sweden does. WI is a remuneration model that is served by data from RWIS (mentioned earlier). As the survey shows, the road networks in all 
the responding countries are equipped with the RWIS. The crucial components of a payment mechanism for remuneration of performed winter maintenance tasks can be highlighted and summarised in Table 3.

\begin{tabular}{|c|c|c|c|c|c|c|c|c|c|c|c|}
\hline \multirow{3}{*}{ Country } & \multirow{2}{*}{\multicolumn{2}{|c|}{$\begin{array}{l}\text { Winter maintenance } \\
\text { services }\end{array}$}} & \multirow{3}{*}{$\begin{array}{c}\text { Contract } \\
\text { period } \\
\text { (year) }\end{array}$} & \multirow{3}{*}{$\begin{array}{c}\text { Option } \\
\text { in } \\
\text { contract }\end{array}$} & \multirow{2}{*}{\multicolumn{2}{|c|}{ RWIS maintenance }} & \multirow{3}{*}{$\begin{array}{l}\text { WI } \\
\text { access } \\
\text { for } \\
\text { cost } \\
\text { control }\end{array}$} & \multicolumn{4}{|c|}{ Payment mechanism } \\
\hline & & & & & & & & \multicolumn{2}{|c|}{ Remuneration } & \multirow[b]{2}{*}{ Penalty } & \multirow[b]{2}{*}{ Bonus } \\
\hline & $\begin{array}{l}\text { Bundled } \\
\text { in road } \\
\text { contract }\end{array}$ & $\begin{array}{l}\text { Separate } \\
\text { contract }\end{array}$ & & & $\begin{array}{l}\text { Bundled } \\
\text { in road } \\
\text { contract }\end{array}$ & $\begin{array}{l}\text { Separate } \\
\text { contract }\end{array}$ & & $\begin{array}{c}\text { Variable* } \\
\text { (Unit- } \\
\text { price) }\end{array}$ & $\begin{array}{l}\text { Fixed- } \\
\text { price }\end{array}$ & & \\
\hline $\begin{array}{l}\text { Canada } \\
\text { (Ontario) }\end{array}$ & $\mathrm{x}$ & - & $\geq 10$ & - & - & $\mathrm{X}$ & Yes & - & $x$ & Yes & No \\
\hline Denmark & $\mathrm{X}$ & - & 4 & 2 & - & $\mathrm{X}$ & Yes & $\mathrm{X}$ & - & No & No \\
\hline Finland & $\mathrm{X}$ & - & $5-7$ & No & $x$ & - & Yes & $\mathrm{x}$ & $\mathrm{X}$ & Yes & Yes \\
\hline Iceland & - & $\mathrm{X}$ & $3-5$ & $2(1+1)$ & - & $\mathrm{X}$ & Yes & $\mathrm{X}$ & $\mathrm{X}$ & No & No \\
\hline Lithuania & $\mathrm{X}$ & - & 1 & No & - & $x$ & No & $\mathrm{X}$ & - & Yes & No \\
\hline Estonia & $\mathrm{X}$ & - & $5-8$ & No & - & $\mathrm{X}$ & No & - & $\mathrm{X}$ & No & No \\
\hline Sweden & $x$ & - & $4-6$ & $2(1+1)$ & - & $x$ & Yes & $x$ & $x$ & $Y_{e}^{* *}$ & Yes** \\
\hline
\end{tabular}

Table 3 International benchmarking of winter road maintenance contracts

Due to the limited response to the benchmarking survey, it is uncertain to what extent WI is used in other countries.

\section{Discussion}

Two fundamentally different main forms of payment appear in the AMC, namely fixed price and variable payment. The second form is related to the amount of work performed on the basis of unit-price. Jacobson (2004) states that these remuneration forms rarely appear completely separate from each other. This is partly because an assignment can very rarely be specified with full certainty in advance, and partly because the activities are often associated with greater risks in certain areas than in others.

One of the payment models uses the Winter Index in which different kinds of registered weather situations within the main groups of slippery and snow are already priced in the bill of quantities. The contractor will receive payment in accordance with unit-price for each situation (Table 1). As our investigation revealed, one of the uncertainties with the model is that the selection of the WI outcome determines the payment, not the contractor's real performed measures. Another uncertainty with the model is the way in which the number of weather outcomes is measured and noted in the procurement specification. Weather data statistics from past years are usually used for new contracts. There is also uncertainty due to problematic weather conditions, such as fine rain that in the presence of low temperatures can cause slippery road conditions that are difficult to detect. The compensation model can in some cases create uncertainty and confuse the contractor when selecting the correct weather outcome (i.e. whether the selected weather outcome is compensable or not). In such cases, the contractor has to wait for a long time to select actions that are entitled to any payment. This implies a risk of conditions remaining slippery with snow on the road surface because lesser measures are taken, which in turn jeopardises road safety.

Another aspect of uncertainty is the measurability of the performed work in order to be paid fairly. Milgrom \& Roberts (1992, p. 369) state that this is one reason for using fixed pay when performance and productivity are difficult to measure with any accuracy or even to describe in sufficient detail. According to the survey, the outcome of the WI system is strongly influenced by a number of factors (e.g. climate factor). Wesström \& Böhm (2008) found that some of these factors can be attributed to the local characteristics of a maintenance area. As this current study reveals, there are disagreements between the client and contractor concerning types of weather situations or events (e.g. the amount of HR1, HR2 or SV1 or SV2). This is due to the definitions and measurement methods that are not optimum. 
As mentioned earlier, RWIS is a system of weather stations for collecting weather data to help contractors plan winter road maintenance (see Abdi, Lind \& Birgisson, 2012) and then get paid for the tasks performed. This system needs to be maintained and serviced in order to provide accurate weather data in real time. Operation and maintenance of this system is performed according to a separate contract called a framework agreement. Earlier studies (Abdi, Lind \& Birgisson, 2012) revealed that the maintenance of this system has not kept up with the performance of those winter tasks that are stated in the AMC. Inaccurate weather data collected in the WI system leads to inaccurate outcomes of the WI. This, in turn, affects the accuracy of the amount of performed winter tasks, culminating in the creation of fuzzy invoices.

Analysis of the contract documents showed that when weather data is missing due to the failure of one or more weather stations, the weather outcome has to be calculated as follows to get invoices as accurate as possible: If a combination of the values from any of the selected MESAN and RWIS stations is available, then the average of the combination is used during the failure period. If values from all combinations are missing, then real resource capacity is reimbursed according to the legal agreement ABT 06 chapter 6 , while the stations are repaired. From a broader perspective, Milgrom \& Roberts (1992, p. 369) state, 'Attempting to pay for performance in these circumstances may actually amount to little more than a random payment policy'. This statement can be interpreted to mean that compensating a contractor according to the real resource capacity of the entrepreneur implies a more reliable payment mechanism than the payment according to $\mathrm{WI}$ outcome. Payment is made monthly, but a final reconciliation of the number of weather outcomes is done when the winter season ends.

In one of the investigated maintenance areas, both the contractor and the client were very satisfied with RWIS-based remuneration for the past winter season. However, the same survey showed that a number of weather stations in the maintenance area had errors and repair took so long that winter was over before they were operational. The study also shows that the assigned RWIS contractor had delayed repair and maintenance of weather stations due to delays in previous payments by the client.

\section{Conclusion and Recommendations}

This study, which is the concluding part of a broader research project undertaken in Sweden, focuses on the forms of remuneration in road maintenance contracts. Its main focus is to provide deeper knowledge and understanding of the payment mechanism for winter maintenance tasks in Sweden that are integrated in more comprehensive contracts and bundled with other road maintenance services. As the earlier studies revealed (Abdi, Lind \& Birgisson, 2013b), several road maintenance services are bundled in a questionable manner in current Swedish road maintenance contracts. Focusing on the payment mechanism and the possibilities of improving it, the general conclusion and recommendations are as follows: From a risk allocation perspective, the combination of a fixed part and a weather dependent part seems to be the rational choice. A large client organisation with a number of AMC can pool the weather risks over the whole country, whereas small contractors may have problems if they enter into a fixed price contract and encounter a severe winter.

The weather dependent part in the Swedish contract is to a large extent also a fixed price contract, in the sense that there is no relation to the actions carried out by the contractor. The exceptions are when there are very special weather conditions. As both theory and the international questionnaire suggest, a fixed price contract creates a risk that the contractor does too little, especially when there are vague stipulations in the contract.

The issue of monitoring actual road conditions in relation to the demands in the contract is very important for applying proper road maintenance measures and payment methods. Monitoring of work performance is, however, costly and will always be imperfect when there

Abdi, A et al (2013) 'Payment mechanisms for winter road maintenance services', Australasian Journal of Construction Economics and Building, 13 (4) 18-31 
are rapidly changing conditions. This means that it is very important to think in terms of creating long-term incentives for the contractor not to use loopholes in the contract and in the payment mechanism. One way to do this is bonuses related to general performance. The Swedish bonus model is currently only applied for salt consumption and control, but it would be very interesting to test the effect of bonuses in relation to customer satisfaction. Customer satisfaction could be measured by questionnaires given to road users. The bonuses can be related to absolute levels of customer satisfaction and to relative customer satisfaction (i.e. how satisfied they are in this district compared to other districts). Bonuses related to internal satisfaction could also be tested and could, for example, be based on questionnaires to the client's staff that has been working with the contractor in question.

As argued in another study (Abdi, Lind \& Birgisson, 2013a), the use of a partnering concept in winter maintenance contracts might be rational, as this creates more flexibility. If such a contract contributes to establishing trust between the parties, it would also reduce the incentives for the contractor to exploit imperfections in the contract.

Another important aspect of creating long term incentives for the contractor is discussed in another study (Abdi, Lind \& Birgisson, 2013b) and relates to the procurement process for contractors. Incentives are strengthened if contractor performance in the current period is an important determinant of whether the contractor will get the contract for the coming period. This can be achieved both by options in the current contract and by giving large weight to earlier performance when contractors are selected. Documented customer and client satisfaction can be the foundation for such an evaluation.

Predicting the effect of a certain payment mechanism is difficult and therefore systematic experimentation is important. A specific mechanism can then be tested and evaluated in a smaller number of AMC before using it on a larger scale.

\section{References}

Abdi, A., Lind, H. \& Birgisson, B. (2013a) 'Effective winter highway maintenance through application of partnering concept', International Journal of Economics and Management Engineering, 3 (3), 112-125, DOI:10.5963/IJEME0303003

Abdi, A., Lind, H. \& Birgisson, B. (2013b) 'Public procurement of winter road maintenance services based on EU procurement directive: Lessons from Sweden', Journal of Investment and Management, 2 (4), 70-86, doi:10.11648/j.jim.20130204.11

Abdi, A., Lind, H. \& Birgisson, B. (2013c) 'Designing appropriate contract for achieving efficient winter road and railway maintenance with high performance quality: A survey of the state of practice in Sweden', Accepted for publishing in the International Journal of Quality and Service Sciences, 1st April 2013

Abdi, A., Lind, H. \& Birgisson, B. (2012) 'Use of Road Weather Information System (RWIS) as assistive tool for effective winter road maintenance: Technical and contractual interactions', International Journal of Engineering and Technology, 2 (12), 2002-2012

Abdi, A. (2012) 'Winter road maintenance on contractual basis: An international benchmarking', Manuscript for Research Rep., Royal Institute of Technology - KTH, Stockholm, Sweden

Abdi, A. (2011) 'Technical and contractual aspects in winter highway and railway operation and maintenance: A survey of current technical systems and contract forms in Sweden', Licentiate thesis, TRITA-VBT 11:08, ISSN 1650-867X, Royal Institute of Technology - KTH, Stockholm, Sweden

Aziz, A. M. A. (2007) 'A survey of the payment mechanisms for transportation DBFO projects in British Columbia', Construction Management and Economics, 25 (5), 529-543

Department of the Environment and Local Government (2000) 'Payment Mechanisms', Public Private Guidance Note 12, 14 April 2000, Dublin, Rep. of Ireland 
European COST 344 Action, Improvements to Snow and Ice Control (2002) 'WINTERTERM - Dictionary of Terms for Winter Maintenance on European Roads and Bridges', Durth Roos Consulting $\mathrm{GmbH}$, Germany

Jaarsma, C. F. \& Dijk, T. van. (2002) 'Financing local rural road maintenance. Who should pay what share and why?', Transport Research Part A, 36, 507-524

Judi, S. S. \& Rashid, R. A. (2010) 'Contractor's right of action for late or non-payment by the employer', Journal of Surveying, Construction \& Property, 1 (1), 65-95

Laurinavicius, A. \& Jukneviciute-Zilinskiene, L. (2011) 'Eleven years of RWIS operation in Lithuania: Possibilities for the use of the data collected', $8^{\text {th }}$ International Environmental Engineering Conference, 19-20 May, Vilnius, Lithuania

Mattsson, H-Å. \& Lind, H. (2009) 'Experiences from procurement of integrated bridge maintenance in Sweden', European Journal of Transport and Infrastructure Research, 9 (2), 143-163

Milgrom, P. \& Roberts, J. (1992) 'Economics, Organization and Management', Prentice Hall, New Jersey, USA

Motawa, I. \& Kaka, A. (2008) 'Payment mechanisms for integrated teams in construction', Australasian Journal of Construction Economics and Building', 8 (2), 1-10

Motawa, I. \& Kaka, A. (2009) 'Modelling payment mechanisms for supply chain in construction', Engineering, Construction and Architectural Management', 16 (4), 325-336

Ng, T. S. \& Wong, Y. M. W. (2007) 'Payment and audits mechanisms for non-private-funded PPP-based infrastructure maintenance projects', Construction Management and Economics, 25(9), 915-923

Ramachandra, T. \& Rotimi, J. O. (2011) 'The nature of payment problems in the New Zealand construction industry', Australasian Journal of Construction Economics and Building, 11 (2), 22-33

Råsled, B. (1992) 'Building and Civil Engineering Contracting', Byggförlaget, Stockholm, Sweden

Stenbeck, T. (2004) 'Incentives to innovations in road and rail maintenance and operations', Licentiate thesis, TRITA-INFRA 04-038, ISSN 1651-0216, Royal Institute of Technology $\mathrm{KTH}$, Stockholm, Sweden

Stenbeck, T. (2009) 'Budgeting performance-based winter maintenance: snow influence on highway maintenance cost', Journal of infrastructure systems. 15 (3), 251-260

Strong, C., Shvetsov, Y. \& Sharp, J. (2005) 'Development of roadway weather severity index', Final Technical Report, Collage of engineering, Montana State University, Montana, USA

Swedish Construction Federation (2006) 'General Conditions of Contract for Design and Construct Contract for Building, Civil Engineering and Installation Works - ABT 06', (Allmänna Bestämmelser för Totalentreprenader avseende byggnads-, anläggnings- och installationsarbeten), Stockholm, Sweden

Swedish Transport Administration - STA (2005) 'Road maintenance contract', Contract documents to Edsby maintenance area, Gävle, Sweden

Swedish Transport Administration - STA (2008) 'Road maintenance contract', Contract documents to Bollnäs maintenance area, Gävle, Sweden

Swedish Transport Administration - STA (2009) 'Road maintenance contract', Contract documents to Borlänge maintenance area, Gävle, Sweden

Swedish Transport Administration - STA (2009) 'Road maintenance contract', Contract documents to Borås maintenance area, Gothenburg, Sweden 
Swedish Transport Administration - STA (2009) 'Rules on measuring and payment for basic maintenance package', General regulations, Borlänge, Sweden

Swedish Transport Administration - STA (2012) 'Road maintenance contract', Contract documents to Väsby maintenance area, Stockholm, Sweden

Swedish Transport Administration - STA (2012) 'Rules on measuring and payment', Contract enclosure to Väsby maintenance area contract, Stockholm, Sweden

Swedish Transport Administration - STA (2013) 'Winter road maintenance', Working material, Borlänge, Sweden

Tighe, S. L., Mills, B., Haas, C. T. \& Baiz, S. (2007) 'Using Road Weather Information Systems (RWIS) to control load restrictions on gravel and surface-treated highways', Technical Report, Ministry of Transportation, Engineering Standards Branch Report, Ontario, Canada

Venäläinen, A. \& Kangas, M. (2003) 'Estimation of winter road maintenance costs using climate data', Meteorol. Appl. 10, 69-73, DOI: 10.1017/S1350482703005073

Wesström, D. \& Böhm, H. (2008) 'Follow-up of the Skanska's operation activities: Winter road maintenance during 2007, MSc thesis, Lund Institute of Technology with Lund University, Lund, Sweden

World Road Association, (2010) 'Snow and Ice databook', Technical committee B5, Winter service, ISBN 978-2-550-57709-6, Québec, Canada 